\title{
Application of a new methodology for the synthesis of $\alpha$-methyl- $\alpha$-arylglycines using methyl acetamidoacrylate as an $\alpha$-methylglycine cation equivalent
}

\author{
Elena Royo, Pilar López* and Carlos Cativiela* \\ Departamento de Química Orgánica, ICMA, Universidad de Zaragoza-CSIC, \\ 50009 Zaragoza, Spain \\ E-mail: cativiela@unizar.es
}

Dedicated to Professor Eusebio Juaristi on the occasion of his $55^{\text {th }}$ birthday (received 04 Mar 05; accepted 12 Apr 05; published on the web 14 Apr 05)

\begin{abstract}
Lewis acid-catalyzed Friedel-Crafts reactions are useful for the synthesis of $\alpha$-aryl- $\alpha$ methylglycines. Reaction of methyl acetamidoacrylate 1 with anisole and phenol has been optimized and a short two-steps synthesis of amino acids $\alpha$-methyl- $\alpha$-(4-methoxyphenyl)glycine (5) and $\alpha$-methyl- $\alpha$-(4-hydroxyphenyl)glycine (9) was achieved with excellent yields. A new route is described to obtain both enantiomers of amino acids 5 and 9 by resolution of the racemic mixture using chiral high performance liquid chromatography.
\end{abstract}

Keywords: Electrophilic aromatic substitution, $\alpha$-aryl- $\alpha$-methylglycines, $\alpha$-methylglycine cation, chiral HPLC

\section{Introduction}

It is well known that $\alpha$-amino acids are vital to life as building blocks for peptides, proteins and many other natural products. Beside the 20 proteinogenic amino acids, the number of known naturally occurring unusual structures is constantly increasing. ${ }^{1}$ An interesting non-proteinogenic class of amino acids are the arylglycines, most of them obtained from natural antibiotics, although also a number of unique synthetic arylglycines have been designed to be used as sidechain moiety of semi synthetic penicillins and cephalosporins. ${ }^{2}$

In recent years, $\alpha, \alpha$-disubstituted glycines have focused a great interest because their incorporation into peptides stabilise some secondary structures and increase the peptide stability toward biological and chemical degradation, so they have been used as enzyme inhibitors for investigation of enzymatic mechanisms. ${ }^{3}$ Over and above that, many $\alpha, \alpha$-disubstituted glycines also possess an important biological activity, including some $\alpha$-alkylated arylglycine derivatives. 
For instance, the simplest member of the family, $\alpha$-methyl- $\alpha$-phenylglycine, $(\alpha \mathrm{Me}) \mathrm{Phg}$, has been incorporated in analogues of aspartame ${ }^{4}$ as well as in tripeptides used as thrombin inhibitors. ${ }^{5}$ Similarly, a tetrapeptide mimetic derived from $\alpha$-methyl- $\alpha$-(4-cyanophenyl)glycine inhibited human platelet aggregation and it could be used for treatment of thrombosic diseases. ${ }^{6}$

However, the most significant biological activity of $\alpha$-alkyl- $\alpha$-arylglycines is their effect on the metabotropic glutamate receptors. It is now accepted that $(S)$-glutamate is the principle excitatory neurotransmitter in the vertebrate nervous system, ${ }^{7}$ acting at a wide variety of glutamate receptor subtypes. ${ }^{7,8}$ These glutamate receptors can be divided into two general classes: ionotropic glutamate (iGlu) receptors and metabotropic glutamate (mGlu) receptors. ${ }^{7,8 b}$ In order to better characterize the different synaptic functions for different subtypes, selective antagonists are very much required. Since the Watkins' pioneering work, ${ }^{9}$ a number of phenylglycine derivatives have been identified as selective antagonists for mGlu over iGlu receptors. One of the first antagonist to show selectivity for mGlu over iGlu receptors was $(S)$ $(+)$ - $\alpha$-methyl- $\alpha$-(4-carboxyphenyl)glycine, (+)-M4CPG, which displayed activity at all three groups of mGlu receptors. ${ }^{7,8 a 9}$ Some other $\alpha$-alkylated arylglycine derivatives have also been found to be selective antagonist of the metabotropic glutamate receptors (mGluRs). ${ }^{10}$

In recent years there has been much interest in the possible therapeutic applications of mGlu receptor ligands. Before the therapeutic potential and physiological significance of the mGluR subtypes can be fully explored, it is necessary to develop potent and selective ligands for these receptors. Therefore, efficient routes for synthesizing enantiopure $\alpha$-methyl- $\alpha$-arylglycines are of major interest to make them useful as pharmacological tools to understand the roles of mGluRs in neuronal synaptic functions. Whereas a wide variety of synthetic routes for construction of chiral $\alpha, \alpha$-disubstituted $\alpha$-amino acids has been reported, ${ }^{3}$ only a few synthetic approaches to the $\alpha$-alkyl- $\alpha$-arylglycines have been developed, including asymmetric synthesis and resolution of racemic mixtures.

Stereoselective $\alpha$-alkylation of cyclic compounds ${ }^{11}$ and asymmetric Strecker synthesis ${ }^{12}$ are the mostly used approaches to optically pure $\alpha$-methyl- $\alpha$-arylglycines. Alkylation of chiral, nonracemic arylglycine enolates derived from bis-lactims, ${ }^{11 \mathrm{a}}$ oxazinones, ${ }^{11 \mathrm{~b}, \mathrm{c}}$ imidazolidinones ${ }^{11 \mathrm{~d}, \mathrm{e}}$ and oxazolidinones ${ }^{11 \mathrm{f}}$ afforded $\alpha$-alkyl- $\alpha$-arylglycines with good diastereoselectivity. However, these methods need many steps for the preparation of the target molecules and the synthesis is restricted to the availability of the corresponding $\alpha$-arylglycine, being used almost exclusively to obtain $\alpha$-methyl- $\alpha$-phenylglycine. On the other hand, although the Strecker reaction has been the most widely used method for the synthesis of arylglycines, only two examples on the application of this reaction to the synthesis of $\alpha$-alkyl- $\alpha$-arylglycines have been reported. ${ }^{12}$ This limited success is probably due to the poor reactivity of the ketones towards the Strecker conditions. Aside these two principal routes, some other stereoselective strategies based in sterocontrolled rearrangements have been reported to obtain $\alpha$-methyl- $\alpha$-phenylglycine. ${ }^{13}$

With regard to racemic synthesis and further resolution, the literature reports only a few examples. Different $\alpha$-alkyl- $\alpha$-phenylglycines were prepared by alkylation of a phenylglycine 
derivative and subsequent separation of the diastereomeric peptides by crystallisation, ${ }^{14}$ which involves the introduction of additional synthetic steps to the pathway towards the final products. On the other hand, racemic Strecker ${ }^{9,10 a}$ or Bücherer ${ }^{15}$ reaction followed by resolution (fractional crystallisation of diastereomeric salts, ${ }^{9,10 a}$ separation of the diastereomeric dipeptides ${ }^{15 \mathrm{a}}$ or a new variant of preferential crystallisation without using a resolving agent) ${ }^{15 \mathrm{~b}}$ have exclusively been applied to the synthesis of (+)-M4CPG.

To the best of our knowledge, no other racemic routes have been developed to access to both enantiomers of $\alpha$-alkyl- $\alpha$-arylglycines, so we would like to report here a completely different strategy for the synthesis of $\alpha$-methyl- $\alpha$-arylglycines in enantiomerically pure form, through a racemic Friedel-Crafts reaction and further resolution by HPLC using a polysaccharide-derived chiral stationary phase.

\section{Results and Discussion}

\section{Synthesis of racemic $\alpha$-methyl- $\alpha$-arylglycines}

$\mathrm{N}$-acyl- $\alpha, \beta$-didehydroamino acids have proved to be useful intermediates in the asymmetric and non-asymmetric synthesis of $\alpha$-amino acids. Methyl 2-acetamidoacrylate 1, one of the simplest compounds of this family, is known to behave as dienophile, ${ }^{16}$ dipolarophile, ${ }^{17}$ and electrophile in Michael type reactions. ${ }^{18}$ In addition, it is able to act as an electrophile in Lewis acid-catalyzed Friedel-Crafts reactions, as we reported previously ${ }^{19}$ (Scheme 1). This reaction can be considered proceeding via an electrophilic acyliminium ion $\mathbf{2}$ that is in equilibrium with the enamine form $\mathbf{1}$ in the presence of the Lewis acid. A similar intermediate has been proposed in the Lewis acidmediated coupling of $\alpha$-trimethylsilylether of $\mathrm{N}$-formylalanine with allylsilanes. ${ }^{20}$ So methyl 2acetamidoacrylate 1 behaves as an equivalent of $\alpha$-methylglycine cation and is able to perform the $\alpha$-amidoalkylation reaction on the aromatic ring, leading to the corresponding methyl $N$ acetyl- $\alpha$-methyl- $\alpha$-arylglycinates.

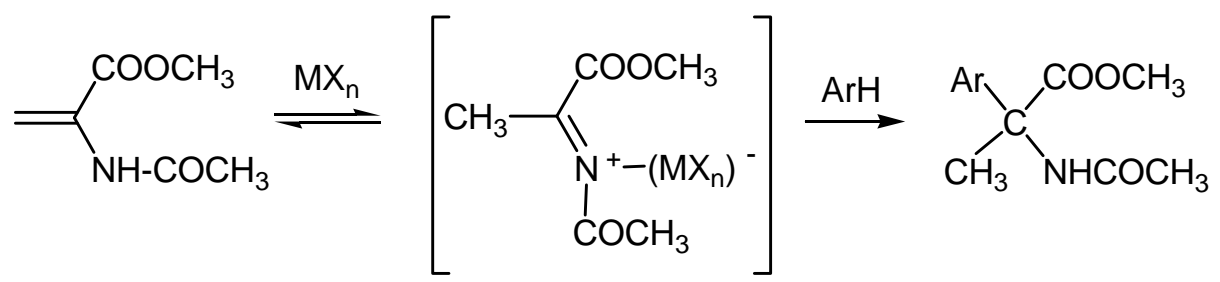

1

2

\section{Scheme 1}

Therefore, we applied our methodology to the preparation of $\alpha$-methyl- $\alpha$-arylglycines in a racemic form. Since anisole had proved to be reactive toward the $\alpha$-amidoalkylation, our first challenge was to obtain amino acid $\alpha$-methyl- $\alpha$-(4-methoxyphenyl)glycine. 
The results of the $\alpha$-amidoalkylation depend on the reaction conditions and the Lewis acid used as a catalyst. ${ }^{19,21}$ Our previous studies on the Friedel-Crafts reaction between methyl 2acetamidoacrylate and aromatic compounds showed that, under homogeneous reactions, the best results were obtained using boron trifluoride etherate as a catalyst. ${ }^{19}$ For this reason, all reactions studied were performed in the presence of this Lewis acid as a catalyst.

First, we optimized the previously described conditions $\left(\mathbf{1} / \mathrm{BF}_{3} \cdot \mathrm{Et}_{2} \mathrm{O} /\right.$ anisole $1 / 1.1 / 4$, $\mathrm{CH}_{2} \mathrm{Cl}_{2}$, room temperature) for the Friedel-Crafts reaction. Although nearly complete conversions were observed by ${ }^{1} \mathrm{H}-\mathrm{NMR}$, yields were only about $60 \%$, probably due to polymerization of methyl 2-acetamidoacrylate (this decomposition had previously been observed in reaction of 1 with cyclopentadiene). ${ }^{16 \mathrm{~b}}$ We tested different conditions to increase the reactivity of 1 toward the $\mathrm{S}_{\mathrm{E}} \mathrm{Ar}$ avoiding the competitive decomposition reaction and the results are shown in Table 1.

Table 1. $\mathrm{BF}_{3} \cdot \mathrm{Et}_{2} \mathrm{O}$-catalysed Friedel-Crafts reaction of $\mathbf{1}$ with anisole

\begin{tabular}{ccccccc}
\hline entry & $\mathbf{1}_{\mathbf{B} \mathrm{BF}_{3} / \text { anisole }}$ & time $^{\mathrm{a}}$ (days) & $\mathrm{T}\left({ }^{\circ} \mathrm{C}\right)$ & conversion $^{\mathrm{b}}(\%)$ & yield $^{\mathrm{c}}(\%)$ & $o-/ p$-ratio \\
\hline 1 & $1 / 1.1 / 4$ & 4 & 25 & 87 & 57 & $1 / 2.4^{\mathrm{b}}$ \\
2 & $1 / 1.1 / 4$ & 7 & 25 & 100 & 40 & $1 / 2.6^{\mathrm{b}}$ \\
3 & $1 / 1.1 / 4$ & 4 & 40 & 100 & 42 & $1 / 3.0^{\mathrm{c}}$ \\
4 & $1 / 1.1 / 8$ & 4 & 25 & 97 & 65 & $1 / 2.8^{\mathrm{b}, \mathrm{c}}$ \\
5 & $1 / 2.5 / 4$ & 4 & 25 & 96 & 66 & $1 / 2.5^{\mathrm{b}}$ \\
6 & $1 / 2.5 / 8$ & 4 & 25 & 97 & 78 & $1 / 3.0^{\mathrm{b}, \mathrm{c}}$ \\
$7^{\mathrm{d}}$ & $1 / 2.5 / 8$ & 4 & 25 & 100 & 40 & $1 / 2.2^{\mathrm{b}}$ \\
\hline
\end{tabular}

${ }^{\mathrm{a}} \mathrm{No}$ more reaction was observed by TLC; ${ }^{\mathrm{b}}$ determined by ${ }^{1} \mathrm{H}-\mathrm{NMR}$; ${ }^{\mathrm{c}}$ determined from isolated products; ${ }^{\mathrm{d}}$ reaction was performed using methyl 2-benzamidoacrylate as starting product.

As can be seen in Table 1, more time or higher temperature led to a higher conversion, but yields were not improved (entries 2, 3). Increasing catalyst or anisole proportion was successful for the $\alpha$-amidoalkylation (entries 4,5 ) and this effect was enhanced when both were simultaneously applied (entry 6). Methyl 2-benzamidoacrylate also behaves as an equivalent of the $\alpha$-methylglycine cation, but the results are poorer (entry 7). Finally, the best conditions (entry 6) provided in a reproducible manner the main compound methyl N-acetyl- $\alpha$-methyl- $\alpha-(4-$ methoxyphenyl)glycine $\mathrm{rac}-\mathbf{3}$ that can be easily separated by column chromatography of its ortho-isomer rac-4. Then, subsequent deprotection of the amino and the carboxylic functions in compound $\mathrm{rac}-3$ by treatment with concentrated $\mathrm{HCl}$ provided the hydrochloride of $\alpha$-methyl- $\alpha$ (4-methoxyphenyl)glycine rac-5 in an excellent yield (Scheme 2). 


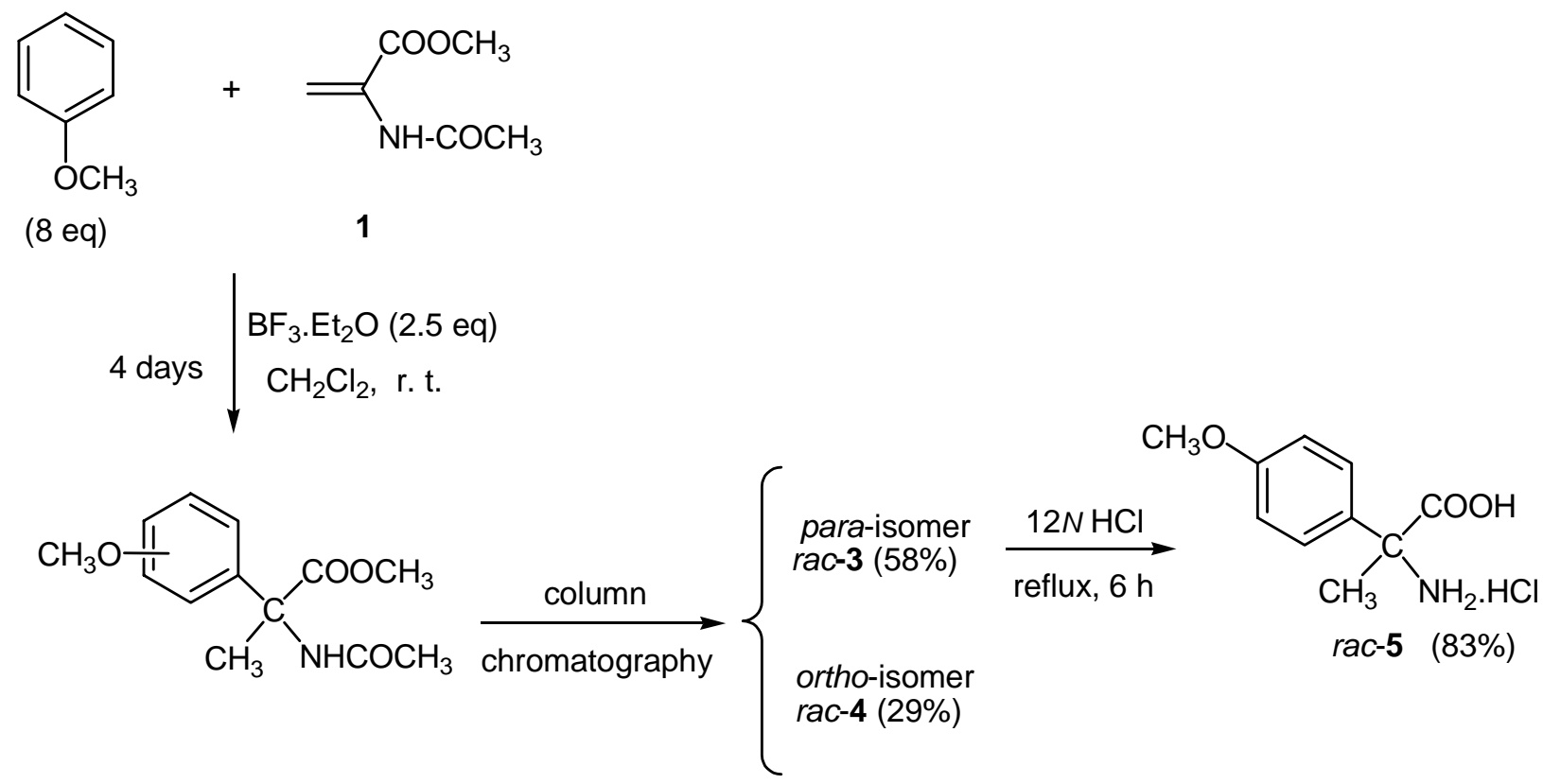

\section{Scheme 2}

With the aim to extend this strategy to a general synthesis of $\alpha$-methyl- $\alpha$-arylglycines, we attempted the reaction with other aromatic carbocycles. Therefore, we tested some benzene derivatives having different groups affecting reactivity in electrophilic aromatic substitutions, as bromobenzene, benzonitrile, toluene, phenyl acetate, phenyl benzoate, acetanilide or phenol. Unfortunately, only strongly activated systems (anisole, phenol) are useful to react with methyl 2 -acetamidoacrylate 1 . This behavior has also been found under heterogeneous catalyst, ${ }^{21}$ but, in that case, phenol and anisole were not even activated toward the $\alpha$-amidoalkylation.

Then, phenol was investigated as starting material in the synthesis of $\alpha$-methyl- $\alpha-(4-$ hydroxyphenyl)glycine. In presence of $\mathrm{BF}_{3} . \mathrm{Et}_{2} \mathrm{O}$, phenol reacted with methyl 2acetamidoacrylate 1 to afford methyl $\mathrm{N}$-acetyl- $\alpha$-methyl- $\alpha$-(4-hydroxyphenyl)glycine rac-6 besides the ortho-isomer rac-7 and a lactone $r a c-8$ (Scheme 3). The presence of compound 8 can be explained from an $\alpha$-amidoalkylation followed by a transesterification reaction. A similar product has been described by Ben-Ishai when using glyoxylic acid derivatives as synthetic equivalents of glycine cations in reactions with aromatic compounds. ${ }^{22}$ 


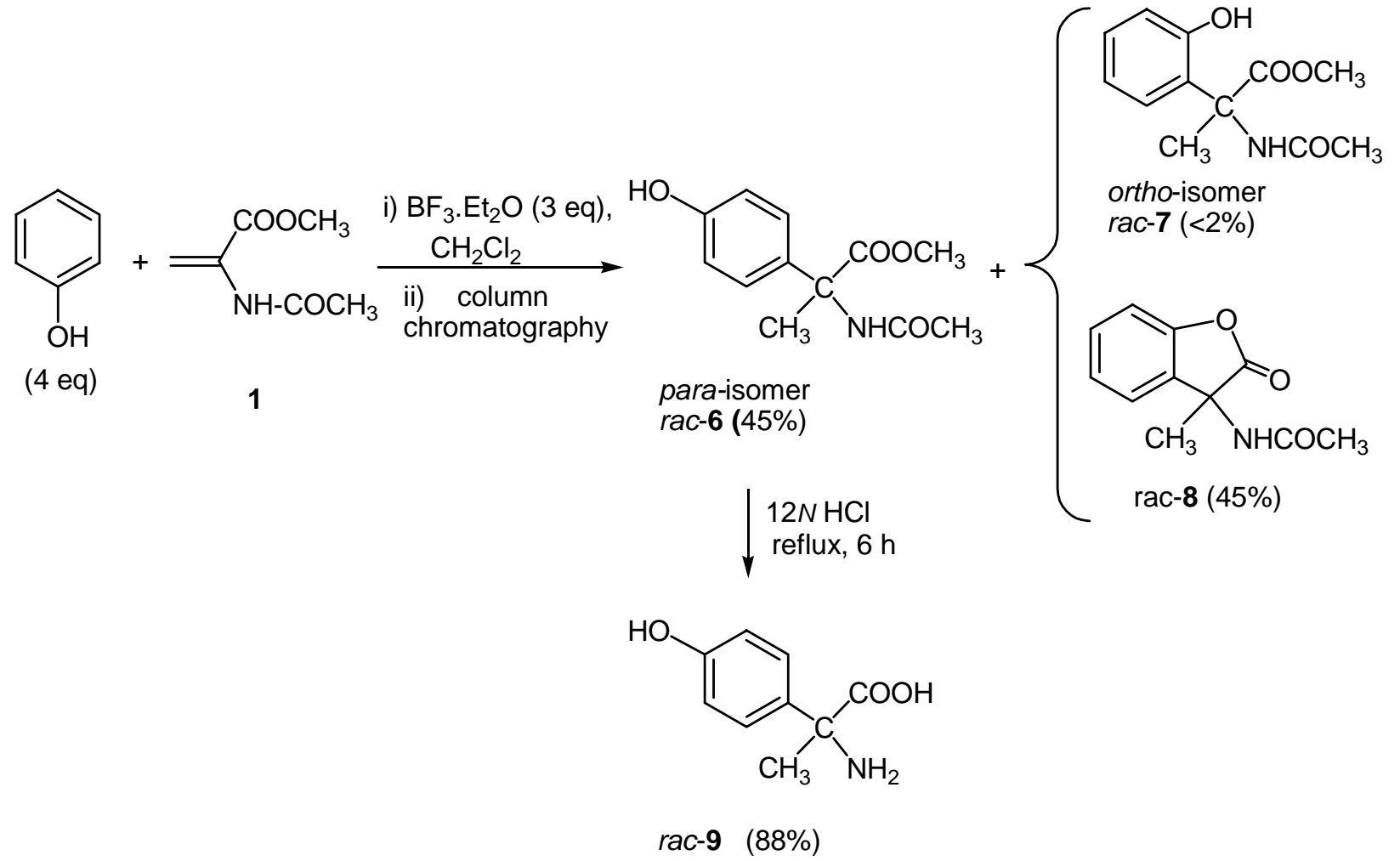

\section{Scheme 3}

Table 2 shows the results of the optimization of the reaction between methyl acetamidoacrylate $\mathbf{1}$ and phenol. Yields of isolated products are higher that obtained starting from anisole (compare results of tables 1 and 2) even at shorter reaction times, accordingly with the higher activation on the aromatic ring. An increase of the $\mathrm{BF}_{3} \cdot \mathrm{Et}_{2} \mathrm{O} / \mathbf{1}$ ratio was sufficient to obtain an excellent yield without an additional excess of phenol (entries 3,4) although lowering the phenol/1 ratio slowed the reaction (entry 2). Unlike that occur in anisole reactions, FriedelCrafts reaction on phenol is ortho-directive ("ortho" includes both ortho-isomer rac-7 and lactone $\mathrm{rac-8}$ ), probably due to the irreversible formation of cyclic compound $\mathbf{8}$. When more catalyst was used, less ortho-isomer rac-7 was detected. In the best conditions (entry 3), an equimolecular mixture of para-isomer rac-6 and cyclic derivative rac-8 as sole products was obtained and the isomers can be easily separated by column chromatography. 
Table 2. $\mathrm{BF}_{3} \cdot \mathrm{Et}_{2} \mathrm{O}$-catalysed Friedel-Crafts reaction of 1 with phenol

\begin{tabular}{cccccc}
\hline entry & $\mathbf{1} / \mathrm{BF}_{3} /$ phenol & $\begin{array}{c}\text { time }^{\mathrm{a}} \\
\text { (days) }\end{array}$ & yield $^{\mathrm{b}}(\%)$ & $\mathbf{6 / 7 / 8}$ ratio $^{\mathrm{c}}$ & $\begin{array}{c}\text { para-isomer }^{\mathrm{b}} \\
\text { (yield, } \%)\end{array}$ \\
\hline 1 & $1 / 1.1 / 4$ & 4 & 78 & $1.2 / 0.5 / 1$ & 35 \\
2 & $1 / 1.1 / 2$ & 6 & 68 & $1.1 / 0.45 / 1$ & 30 \\
3 & $1 / 3 / 4$ & 2 & 90 & $1 / 0 / 1$ & 45 \\
4 & $1 / 5 / 4$ & 2 & 89 & $0.84 / 0.1 / 1$ & 39 \\
\hline${ }^{\mathrm{a}}$ Reaction was completed (TLC, & $\left.{ }^{1} \mathrm{H}-\mathrm{NMR}\right) ;{ }^{\mathrm{b}}$ determined from isolated products; \\
${ }^{\mathrm{c}}$ Determined by ${ }^{1} \mathrm{H}-\mathrm{NMR}$.
\end{tabular}

Finally, the hydrolysis of rac-6 in the same conditions used with compound $\mathrm{rac}-\mathbf{3}$ provided $\alpha$-methyl- $\alpha$-(4-hydroxyphenyl)glycine as hydrochloride (9) in an excellent yield (Scheme 3).

In this way, short two-steps synthesis of amino acids rac-5 and rac-9 from anisole or phenol, respectively, was achieved. To the best of our knowledge this is the first reported synthesis of amino acid $\mathbf{9}$. With regard to amino acid $\mathbf{5}$, we have found in the literature only one reference, a diastereoselective synthesis of the $(S)$-isomer by application of a sulfinimine mediated Strecker reaction using N-sulfinyl ketimines as substrates. ${ }^{12 \mathrm{~b}}$ In our case, spectroscopic data are according with those described.

\section{HPLC resolution of rac-3 and rac-6}

Once an efficient route to the target compounds had been developed, we undertook the preparation of both enantiomers of the amino acids 5 and $\mathbf{9}$ in optically pure form. Although enantiomers can be obtained by the separation of diastereoisomers, the direct separation of enantiomers by preparative chromatography on chiral stationary phases (CSPs) is today recognized as a powerful alternative. ${ }^{23}$ CSPs derived from cellulose and amylose are extremely popular because of their wide applicability and usefulness in enantioselective liquid chromatography. ${ }^{24}$ In this work, two non-commercial polysaccharide-derived supports consisting of mixed 10-undecenoate/3,5-dimethylphenylcarbamate of cellulose and amylose, respectively, covalently attached to allylsilica gel were used. ${ }^{25}$ The covalent immobilization results in an extremely high stability for these phases in the presence of a wide range of solvents. The excellent chiral discrimination exhibited by these stationary phases towards a variety of compounds, together with its high chemical stability, make it especially suitable for resolutions on a preparative scale, as we had already shown in the preparative enantioseparations of different phenylalanine ${ }^{26}$ and other amino acid $^{27}$ surrogates.

Although the mechanism for chiral discrimination on CSPs derived from arylcarbamates of polysaccharides remains ambiguous, the interaction between the carbamate residues of the chiral selector with the racemate, mainly through hydrogen bonding involving the $\mathrm{N}-\mathrm{H}$ and $\mathrm{C}=\mathrm{O}$ groups of the carbamate groups, is proposed as the most important factor for effective enantiodiscrimination. $^{24 \mathrm{~b}}$ In such a case, amido esters rac-3 and rac-6 should be suitable substrates for enantioseparation. 
Then, the HPLC analytical resolution of derivatives $\mathrm{rac}-\mathbf{3}$ and $\mathrm{rac}-\mathbf{6}$ was tested on both columns, CSP-1 (derived from 10-undecenoate/3,5-dimethylphenyl-carbamate of cellulose) and CSP-2 (derived from 10-undecenoate/3,5-dimethylphenylcarbamate of amylose). Different mixtures of $n$-hexane/2-propanol, $n$-hexane/ethanol, $n$-hexane/2-propanol/acetone and $n$ hexane/ethanol/ /acetone were tested as eluents (flow rate $1 \mathrm{~mL} / \mathrm{min}$ ). Tables 3 and 4 contain the most representative results.

Table 3. Selected chromatographic data for the HPLC resolution of rac-3 on CSP-1 and different chromatographic modes ${ }^{[\mathrm{a}]}$

\begin{tabular}{|c|c|c|c|c|c|c|}
\hline entry & $\begin{array}{c}\text { chromatographic } \\
\text { mode }\end{array}$ & eluent $^{[\mathrm{b}]}$ & $\lambda(\mathrm{nm})$ & $k^{\prime}{ }_{1}{ }^{[\mathrm{c}]}$ & $\alpha^{[\mathrm{c}]}$ & $R_{S}^{[\mathrm{c}]}$ \\
\hline 1 & analytical $^{[\mathrm{d}]}$ & $\mathrm{A} / \mathrm{B} \quad 95 / 5$ & 210 & 6.05 & 1.07 & 0.39 \\
\hline 2 & analytical $^{[\mathrm{d}]}$ & $\mathrm{A} / \mathrm{B} \quad 90 / 10$ & 210 & 3.73 & 1.06 & 0.40 \\
\hline 3 & analytical $^{[\mathrm{d}]}$ & $\mathrm{A} / \mathrm{B} / \mathrm{D} 94 / 3 / 3$ & 215 & 4.13 & 1.109 & 1.10 \\
\hline 4 & analytical $^{[\mathrm{d}]}$ & $\mathrm{A} / \mathrm{B} / \mathrm{D} 95 / 3 / 2$ & 215 & 5.42 & 1.13 & 1.27 \\
\hline 5 & analytical $^{[\mathrm{d}]}$ & $\mathrm{A} / \mathrm{B} / \mathrm{D} 95 / 4 / 1$ & 215 & 4.83 & 1.09 & 0.83 \\
\hline 6 & overload $^{[\mathrm{e}]}$ & $\mathrm{A} / \mathrm{B} / \mathrm{D} 95 / 4 / 1$ & 260 & 4.50 & 1.08 & 0.37 \\
\hline 7 & analytical $^{[\mathrm{d}]}$ & A/B/D 94/5.4/0.6 & 215 & 4.49 & 1.09 & 0.76 \\
\hline 8 & overload $^{[\mathrm{e}]}$ & $\mathrm{A} / \mathrm{B} / \mathrm{D} 94 / 5.4 / 0.6$ & 260 & 4.29 & 1.08 & 0.43 \\
\hline 9 & analytical $^{[\mathrm{d}]}$ & $\mathrm{A} / \mathrm{C} / \mathrm{D} 94 / 5.5 / 0.5$ & 215 & 2.33 & 1.06 & 0.42 \\
\hline 10 & analytical $^{[\mathrm{d}]}$ & $\mathrm{A} / \mathrm{C} / \mathrm{D} 97 / 1.6 / 0.4$ & 215 & 6.49 & 1.07 & 0.77 \\
\hline 11 & overload $^{[\mathrm{e}]}$ & $\mathrm{A} / \mathrm{C} / \mathrm{D} 97 / 1.6 / 0.4$ & 260 & 6.31 & 1.07 & 0.61 \\
\hline
\end{tabular}

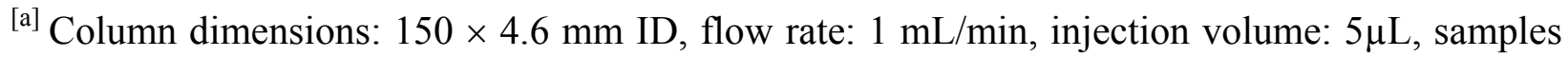
dissolved in ethanol. ${ }^{[\mathrm{b}]} \mathrm{A}: n$-hexane, B: $i \operatorname{PrOH}, \mathrm{C}:$ EtOH, D: acetone. ${ }^{[\mathrm{c}]}$ For the definition of $k^{\prime}$ (capacity factor), $\alpha$ (separation factor) and $R_{S}$ (resolution factor), see Experimental Section. ${ }^{[\mathrm{d}]} \quad c$ $=5 \mathrm{mg} / \mathrm{mL} \cdot{ }^{[\mathrm{e}]} c=100 \mathrm{mg} / \mathrm{mL}$.

Compound rac-3 could not be separated on CSP-2 under any chromatographic conditions explored, but it did on CSP-1, derived from the 3,5-dimethylphenylcarbamate of cellulose (Table 3 ). The use of mixtures of $n$-hexane/2-propanol as eluents did not allow a good separation (entries 1 and 2), but addition of some acetone improved both the selectivity $(\alpha)$ and the resolution $\left(R_{S}\right)$ (entries 3-5). The best analytical chromatographic separation achieved was that involving about $2 \%$ of acetone in the eluent (entry 4 ). However, when a concentrated sample of rac-3 $(c=100 \mathrm{mg} / \mathrm{mL})$ was injected into the analytical column in an overload mode to scale-up the analytical resolution to the semi preparative conditions, saturation of UV detector was observed in all range of $\lambda$ between 190 and $300 \mathrm{~nm}$, due to the absorption of the acetone. Only when the amount of acetone was lower than $1 \%$, detection in the overload mode was possible 
(entry 6), but with a decrease in the $R_{s}$ of the separation. Taking into account this requisite, the optimal eluent was determined as a 94/5.4/0.6 mixture of $n$-hexane/2-propanol/acetone (entries 7 and 8). Since the solubility of the solute is a critical factor in preparative chromatography and rac-3 was much more soluble in ethanol than in 2-propanol, mixtures of $n$ hexane/ethanol/acetone was tested as eluents, leading to better results in overload mode. Taking into account that ethanol is more polar than 2-propanol and induce a decrease in the capacity factor and, hence, in the $R_{s}$ (entry 9), a mixture of $n$-hexane/ethanol/acetone 97/2.4/0.6 was finally chosen to perform the semi preparative resolution (entries 10,11).

Table 4. Selected chromatographic data for the HPLC resolution of rac-6 on several stationary phases and chromatographic modes ${ }^{[\mathrm{a}]}$

\begin{tabular}{|c|c|c|c|c|c|c|c|}
\hline entry & CSP & $\begin{array}{c}\text { chromatographic } \\
\text { mode }\end{array}$ & eluent $^{[\mathrm{b}}$ & $\lambda(\mathrm{nm})$ & $k_{1}^{\prime}{ }^{[\mathrm{c}]}$ & $\alpha^{[\mathrm{c}]}$ & $R_{S}^{[\mathrm{c}]}$ \\
\hline 1 & CSP-1 & analytical $^{[\mathrm{d}]}$ & $\mathrm{A} / \mathrm{B} \quad 95 / 5$ & 220 & 6.55 & 1.00 & - \\
\hline 2 & CSP-1 & analytical $^{[\mathrm{d}]}$ & A/C/D 97/1.6/0.4 & 220 & 10.93 & 1.16 & 0.70 \\
\hline 3 & CSP-2 & analytical $^{[\mathrm{d}]}$ & A/B $90 / 10$ & 220 & 4.49 & 1.11 & 0.52 \\
\hline 4 & CSP-2 & analytical $^{[\mathrm{d}]}$ & $\mathrm{A} / \mathrm{B} / \mathrm{E} 86 / 7 / 7$ & 230 & 5.46 & 1.13 & 0.65 \\
\hline 5 & CSP-2 & analytical $^{[\mathrm{d}]}$ & $\mathrm{A} / \mathrm{C} / \mathrm{E} 93 / 5 / 2$ & 230 & 7.01 & 1.13 & 0.81 \\
\hline 6 & CSP-2 & overload $^{[\mathrm{e}]}$ & $\mathrm{A} / \mathrm{C} / \mathrm{E} 93 / 5 / 2$ & 270 & 6.68 & 1.09 & 0.64 \\
\hline 7 & CSP-2 & analytical $^{[\mathrm{d}]}$ & $\mathrm{A} / \mathrm{C} / \mathrm{E} 91 / 5 / 4$ & 230 & 5.31 & 1.13 & 0.89 \\
\hline 8 & CSP-2 & overload $^{[\mathrm{e}]}$ & $\mathrm{A} / \mathrm{C} / \mathrm{E} 91 / 5 / 4$ & 270 & 5.22 & 1.10 & 0.62 \\
\hline
\end{tabular}

${ }^{\text {[a] }}$ Column dimensions: $150 \times 4.6 \mathrm{~mm}$ ID, flow rate: $1 \mathrm{~mL} / \mathrm{min}$, injection volume: $5 \mu \mathrm{L}$, samples dissolved in ethanol. ${ }^{[\mathrm{b}]} \mathrm{A}$ : $n$-hexane, B: $i \operatorname{PrOH}, \mathrm{C}:$ EtOH, D: acetone, E: chloroform. ${ }^{[\mathrm{c}]}$ For the definition of $k^{\prime}$ (capacity factor), $\alpha$ (separation factor) and $R_{s}$ (resolution factor), see Experimental Section. ${ }^{[\mathrm{d}]} c=5 \mathrm{mg} / \mathrm{mL} .{ }^{[\mathrm{e}]} c=100 \mathrm{mg} / \mathrm{mL}$.

Compound rac-6 was resolved on the both systems CSP-1 and CSP-2 (see Table 4) but $R_{s}$ were not very high in any case, probably due to the poor solubility of the racemate and the subsequent enlarging of the peaks. Binary systems did not work as eluents for the resolution on CSP-1 (as an example, see entry 1), so ternary mixtures of solvents were studied. When the best chromatographic conditions on CSP-1 (a 97/1.6/0.4 mixture of $n$-hexane/ethanol/acetone, entry 2) were scaled-up to overloading mode, resolution of the peaks did not occur. On CSP-2 (derived from the 3,5-dimethylphenylcarbamate of amylose), the optimal separation conditions were determined by adding a certain amount of chloroform to a mixture of $n$-hexane/ethanol (entries 5-8) to enhance the solubility of the compound. The best analytical chromatographic separation was achieved by using a 91/5/4 mixture of $n$-hexane/chloroform/ethanol as the eluent (entries 7 and 8), which gave the highest values for the separation factor $\alpha$ and resolution $R_{s}$. 
Finally, under the conditions described above, the separations of rac-3 and rac-6 were performed at the semi preparative level. HPLC resolution of $\mathrm{rac}-\mathbf{3},(650 \mathrm{mg})$ dissolved in ethanol $(6.5 \mathrm{~mL})$ was carried out by successive injections of $100 \mu \mathrm{L}$ on a $150 \times 20 \mathrm{~mm}$ ID column filled with the 10-undecenoate/3,5-dimethylphenylcarbamate of cellulose bonded on allylsilica gel, using a 97/2.4/0.6 mixture of $n$-hexane/ethanol/acetone as the eluent (flow-rate $18 \mathrm{~mL} \mathrm{~min}^{-1}$ ). Two separate fractions were collected. Evaporation of the first fraction provided $260 \mathrm{mg}$ of the first eluted enantiomer in a 90/10 enantiomeric ratio. The second fraction contained $330 \mathrm{mg}$ of the last eluted enantiomer, in a 98/2 enantiopurity. Evaporation and crystallization from hexane of the second fraction led to $150 \mathrm{mg}$ of the more strongly retained enantiomer in optically pure form. Crystallization of the first fraction led to a solid more enriched in the second enantiomer, probably due to the higher solubility of the enantiomer if comparing with the racemate. Then, the less strongly retained enantiomer $(100 \mathrm{mg})$ was obtained from the liquor mother with a $99 \%$ ee. Likewise, HPLC resolution of rac-6 was carried out on a $150 \times 20 \mathrm{~mm}$ ID column filled with the 10-undecenoate/3,5-dimethylphenylcarbamate of amylose bonded on allylsilica gel. A solution less concentrated than used in the preliminary study $(c=80 \mathrm{mg} / \mathrm{mL})$ was employed, because of the low solubility of the racemate caused eventually its precipitation. Then, a solution of $500 \mathrm{mg}$ of rac-6 in $6.3 \mathrm{~mL}$ of ethanol was injected (repetitive injections of $100 \mu \mathrm{L}$ ) onto the semi preparative column and a 91/5/4 mixture of $n$-hexane/chloroform/ethanol was used as the eluent (flow-rate $18 \mathrm{~mL} \mathrm{~min}^{-1}$ ). Three separate fractions were collected. The first fraction contained $235 \mathrm{mg}$ of the first eluted enantiomer with $98 \%$ ee and the third fraction provided $190 \mathrm{mg}$ of the last eluted enantiomer in a 94/6 enantiomeric ratio. The second fraction (61 mg) contained a $35 / 65$ mixture of the first and the second eluted enantiomers. Crystallization from ethanol of first and last fractions provided, respectively, $190 \mathrm{mg}$ of the less strongly retained enantiomer and 130 $\mathrm{mg}$ of the more retained one, both in optically pure form.

Finally, the resolved enantiomers of $\mathbf{3}$ and $\mathbf{6}$ were subjected to hydrolysis under the conditions previously developed for the racemic material, affording in high yields the desired amino acids $(S)-\mathbf{5},(R)-\mathbf{5},(S)-9$ and $(R)-\mathbf{9}$, respectively, as hydrochlorides.

\section{Assignment of absolute configurations}

Since $(S)-5$ had been described, ${ }^{12 b}$ determination of the specific rotations of the enantiomerically pure amino acid hydrochlorides $\mathbf{5}$ and comparison with the data reported in the literature allowed us to identify the first eluted enantiomer of $\mathbf{3}$ as $(S)$ while to the more strongly retained one was assigned the $(R)$ configuration.

However, enantiomers of $\alpha$-methyl- $\alpha$-(4-hydroxyphenyl)glycine 9 had never been described. In order to assign the absolute stereochemistry of each enantiomer of $\mathbf{6}$, transformation of the first eluted enantiomer of $\mathbf{6}$ into the corresponding enantiomer of $\mathbf{3}$ was carried out by alkylation with methyl iodide in the presence of anhydrous $\mathrm{K}_{2} \mathrm{CO}_{3}$. Measurement of the specific rotation of such obtained enantiomer of $\mathbf{3}$ allowed us to assign an $(R)$ configuration to the less strongly retained enantiomer of $\mathbf{6}$ and an $(S)$ stereochemistry to the last 
eluted one, and also to determine the absolute configuration of their corresponding derived amino acids 9.

\section{Conclusions}

In conclusion, we have shown that Friedel-Crafts reaction between an equivalent of $\alpha$ methylglycine cation, methyl acetamidoacrylate $\mathbf{1}$, and phenol and other activated aromatic rings is possible. The racemic process described here, because of its simplicity and the use of readily available chemicals, appears to be a promising and useful route to a variety of $\alpha$-methyl- $\alpha$ arylglycines, either aromatic $\alpha$-amino acids derived of strongly activated aromatic rings in the electrophilic aromatic substitution, or amino acids obtained by further transformation of activating group. This procedure allowed us to describe, for the first time, the synthesis of $\alpha$ methyl- $\alpha$-(4-hydroxyphenyl)glycine.

Furthermore, resolution of racemic mixtures by chiral semi-preparative HPLC has provided the two enantiomers of $\alpha$-methyl- $\alpha$-(4-methoxyphenyl)glycine and both enantiomers of $\alpha$-methyl- $\alpha$-(4-hydroxyphenyl)glycine.

\section{Experimental Section}

General Procedures. All reagents were purchased from the Aldrich Chemical Co. (Milwaukee, WI) and used without further purification. Solvents were dried, when necessary, by standard methods. The progress of the reactions was checked by thin layer chromatography (TLC) on Merck 60 F240 precoated silica gel polyester plates and products were visualized under UV light (254 $\mathrm{nm}$ ) or ninhydrin chromatic reaction as appropriate. Column chromatography was performed using Merck silica gel $(40-60 \mu \mathrm{m})$. Melting points were determined on a Büchi SMP20 apparatus and were not corrected. IR spectra were registered on a Mattson Genesis FTIR spectrophotometer; $v_{\max }$ is given for the main absorption bands. ${ }^{1} \mathrm{H}$ - and ${ }^{13} \mathrm{C}$ - NMR spectra were recorded on a Varian Unity-300 or a Bruker ARX-300 at room temperature, using the residual solvent signal as internal standard); chemical shifts $(\delta)$ are expressed in ppm and coupling constants $(J)$ in Hertz. Optical rotations were measured in a $10 \mathrm{~cm}$ cell at $25^{\circ} \mathrm{C}$ using a PerkinElmer 241 Polarimeter-C. Elemental analyses were carried out on a Perkin-Elmer 200 C, H, N, S analyzer. HPLC was carried out on a system equipped with a Waters 600-E pump and a Waters 991 photodiode array detector. The preparation of the chiral stationary phases, consisting of mixed 10-undecenoate/3,5-dimethylphenylcarbamate of cellulose or amylose, has been previously described. ${ }^{25}$ The solvents used as mobile phases were of spectral grade. HPLC analytical assays were carried out on a $150 \times 4.6 \mathrm{~mm}$ ID column with an eluent flow rate of $1 \mathrm{~mL}$ $\min ^{-1}$ and UV monitoring at the corresponding $\lambda$ indicated in tables 3 and 4 . The capacity $\left(k_{\mathrm{r}}^{\prime}\right)$, selectivity $(\alpha)$ and resolution $\left(R_{s}\right)$ factors are defined as follows: $k^{\prime}=\left(t_{r}-t_{0}\right) / t_{0}, \alpha=k_{1}^{\prime} / k_{2}^{\prime}, R_{s}=$ 
$1.18\left(t_{2}-t_{1}\right) /\left(w_{2}+w_{1}\right)$, where subscripts 1 and 2 refer to the first and second eluted enantiomer, and $w_{1}$ and $w_{2}$ denote their half-height peak widths; $t_{0}$ is the dead time. The semi preparative resolutions of rac-3 and rac-6 were carried out on a $150 \times 20 \mathrm{~mm}$ ID column. For resolution of rac-3, a mixture of $n$-hexane/ethanol/acetone (97/2.4/0.6) was used as the eluent, at a flow rate of $18 \mathrm{~mL} \mathrm{~min}^{-1}$; UV detection was at $260 \mathrm{~nm}$. For rac-6, the eluent was a 91/5/4 mixture of $n$ hexane/ethanol/chloroform, the flow rate $18 \mathrm{~mL} \mathrm{~min}^{-1}$ and the $\mathrm{UV}$ detection at $270 \mathrm{~nm}$.

\section{$\alpha$-Amidoalkylation of anisole. Synthesis of methyl $N$-acetyl- $\alpha$-methyl- $\alpha$-(4-} methoxyphenyl)glycinate (rac-3). Under an inert atmosphere, $10 \mathrm{mmol} \mathrm{of} \mathrm{BF}_{3}$. Et $\mathrm{m}_{2} \mathrm{O}$ were added at room temperature to a solution of methyl acetamidoacrylate 1 ( $4 \mathrm{mmol})$ in $40 \mathrm{ml}$ of dry $\mathrm{CH}_{2} \mathrm{Cl}_{2}$. After $30 \mathrm{~min}$ of stirring, $32 \mathrm{mmol}$ of anisole was added and the reaction mixture was stirred for 4 days. Work-up began by quenching with $\mathrm{Na}_{2} \mathrm{CO}_{3} \cdot 10 \mathrm{H}_{2} \mathrm{O}$ followed by filtration, evaporation of the solvent and column chromatography $\left(\mathrm{CH}_{2} \mathrm{Cl}_{2} /\right.$ ether $\left.7 / 3\right)$ to obtain the isomers rac-3 (582 mg, 58\%) and rac-4 (201 mg, 20\%). Data for rac-3: white solid, $\mathrm{mp} 120^{\circ} \mathrm{C}(\mathrm{EtOH})$; IR (nujol): $3229,1737,1630 \mathrm{~cm}^{-1} ;{ }^{1} \mathrm{H}-\mathrm{NMR}\left(300 \mathrm{MHz}, \mathrm{CDCl}_{3}\right) \delta 7.36(\mathrm{dd}, J=6.8,1.6 \mathrm{~Hz}, 2 \mathrm{H})$, $6.87(\mathrm{dd}, J=6.8,1.6 \mathrm{~Hz}, 2 \mathrm{H}), 6.65$ (bs, 1H), 3.79 (s, 3H), 3.70 (s, 3H), 2.02 (s, 3H), 2.00 (s, 3H); ${ }^{13} \mathrm{C}-\mathrm{NMR}\left(75 \mathrm{MHz}, \mathrm{CDCl}_{3}\right) \delta 173.70,168.89,159.13,132.18,127.00,113.87,61.49,55.18$, 52.98, 23.73, 22.01. Anal. Calcd. for $\mathrm{C}_{13} \mathrm{H}_{17} \mathrm{NO}_{4}$ : C 62.14, H 6.82, N 5.57; Found: C 61.85, H 6.75, N 5.60. Data for rac-4: oil, IR (nujol): 3416, 1740, $1662 \mathrm{~cm}^{-1} ;{ }^{1} \mathrm{H}-\mathrm{NMR}\left(300 \mathrm{MHz}, \mathrm{CDCl}_{3}\right)$ $\delta 7.58(\mathrm{dd}, J=7.8,1.8 \mathrm{~Hz}, 1 \mathrm{H}), 7.33-7.24(\mathrm{~m}, 1 \mathrm{H}), 7.07(\mathrm{bs}, 1 \mathrm{H}), 7.00(\mathrm{dt}, J=7.8,1.2 \mathrm{~Hz}, 1 \mathrm{H})$, $6.85(\mathrm{dd}, J=8.1,1.2 \mathrm{~Hz}, 1 \mathrm{H}), 3.76(\mathrm{~s}, 3 \mathrm{H}), 3.70(\mathrm{~s}, 3 \mathrm{H}), 2.03(\mathrm{~s}, 3 \mathrm{H}), 1.89(\mathrm{~s}, 3 \mathrm{H}) ;{ }^{13} \mathrm{C}-\mathrm{NMR}(75$ $\left.\mathrm{MHz}, \mathrm{CDCl}_{3}\right) \delta 175.61,168.34,156.14,129.16,128.61,128.49,120.34,111.00,59.74,55.34$, 52.85, 24.09, 21.77.

Resolution of methyl $\mathbf{N}$-acetyl-a-methyl-a-(4-methoxyphenyl)glycinate (rac-3). HPLC resolution of rac-3 $(650 \mathrm{mg})$ dissolved in $\mathrm{CH}_{2} \mathrm{Cl}_{2}(6.5 \mathrm{~mL})$ was carried out by successive injections of $0.1 \mathrm{~mL}$ on a $150 \times 20 \mathrm{~mm}$ ID column filled with mixed 10-undecenoate/3,5dimethylphenylcarbamate of cellulose bonded on allylsilica gel (CSP-1) and using a mixture of $n$-hexane/ethanol/acetone 97/2.4/0.6 as the eluent (flow rate: $18 \mathrm{~mL} / \mathrm{min}$ ). Two separate fractions were collected. The first and last fractions contained, respectively, 90/10 (260 mg) and 2/98 (330 $\mathrm{mg}$ ) mixtures of $(S)-\mathbf{3}$ and $(R)$-3. Crystallization of the first fraction led to a solid more enriched in the second enantiomer. Then, $(S)-\mathbf{3}(100 \mathrm{mg})$ was obtained by evaporation from the liquor mother with a $99 \%$ ee. Crystallization from hexane of the second fraction obtained in the semipreparative resolution led to $150 \mathrm{mg}$ of enantiomerically pure $(R)-\mathbf{3}$.

Spectroscopic data for both $(S)-\mathbf{3}$ and $(R)-\mathbf{3}$ were the same as described above for rac-3.

(S)-(3). $\mathrm{Mp} 103{ }^{\circ} \mathrm{C}$. $[\alpha]_{\mathrm{D}}+68.3\left(c=0.55, \mathrm{CH}_{2} \mathrm{Cl}_{2}, 99 \%\right.$ ee); $(R)-(3)$. Mp $104{ }^{\circ} \mathrm{C}$. $[\alpha]_{\mathrm{D}}-69.5(c=$ $\left.0.25, \mathrm{CH}_{2} \mathrm{Cl}_{2}\right)$.

$\alpha$-Methyl-a-(4-methoxyphenyl)glycine hydrochloride (rac-5). A solution of amido ester rac-3 $(1 \mathrm{~g}, 41 \mathrm{mmol})$ in $12 \mathrm{~N}$ hydrochloric acid $(20 \mathrm{~mL})$ was heated under reflux for $1 \mathrm{~d}$. The solvent was evaporated and the resulting solid was partitioned between diethyl ether and water. The aqueous phase was washed with three additional portions of $\mathrm{Et}_{2} \mathrm{O}$ and then lyophilized to give 
$718 \mathrm{mg}$ of $\mathrm{rac}-5$ (3.33 mmol, 83\% yield). Mp $225^{\circ} \mathrm{C}$. IR (nujol) $1738 \mathrm{~cm}^{-1}$. ${ }^{1} \mathrm{H}$ NMR $\left(\mathrm{D}_{2} \mathrm{O}, 300\right.$ MHz) $\delta 7.45(\mathrm{~d}, J=8.95 \mathrm{~Hz}, 2 \mathrm{H}), 7.06(\mathrm{~d}, J=8.95 \mathrm{~Hz}, 2 \mathrm{H}), 3.85(\mathrm{~s}, 3 \mathrm{H}), 1.90(\mathrm{~s}, 3 \mathrm{H}) .{ }^{13} \mathrm{C}$ NMR $\left(\mathrm{D}_{2} \mathrm{O}, 75 \mathrm{MHz}\right) \delta 174.12,159.75,128.04,127.60,114.69,61.55,55.46,21.04$.

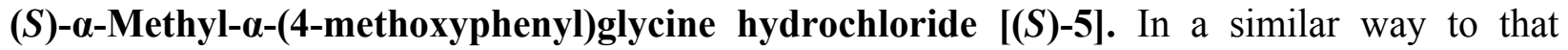
described above, starting from $(S)-3(100 \mathrm{mg}, 0.4 \mathrm{mmol}),(S)-5$ was obtained as a white solid (76.5 mg, $0.35 \mathrm{mmol}, 88 \%$ yield). Spectroscopic data are the same as those described for rac-5. Mp $245-250^{\circ} \mathrm{C}$ (dec.). $[\alpha]_{\mathrm{D}}+28.7\left(c=0.12, \mathrm{H}_{2} \mathrm{O}, 99 \%\right.$ ee).

(R)- $\alpha$-Methyl- $\alpha$-(4-methoxyphenyl)glycine hydrochloride [(R)-5]. An identical procedure to that described above was applied to transform $(R)-3(100 \mathrm{mg}, 0.4 \mathrm{mmol})$ into $(R)-5(70 \mathrm{mg}, 0.32$ mmol, $80 \%$ yield). Spectroscopic data are the same as those described for rac-5. Mp $245-250{ }^{\circ} \mathrm{C}$ (dec.). $[\alpha]_{D}-29.1\left(c=0.20, \mathrm{H}_{2} \mathrm{O}\right)$.

$\alpha$-Amidoalkylation of phenol. Synthesis of methyl $N$-acetyl- $\alpha$-methyl- $\alpha$-(4hydroxyphenyl)glycinate (rac-6). In a similar manner to described for the synthesis of rac-3, reaction between $12 \mathrm{mmol}$ of $\mathrm{BF}_{3} \cdot \mathrm{Et}_{2} \mathrm{O}, 4 \mathrm{mmol}$ of 1 and $16 \mathrm{mmol}$ of phenol was carried out. After 2 days of reaction and the same work-up described above, $p$-isomer rac-6 was isolated by column chromatography in $\mathrm{CH}_{2} \mathrm{Cl}_{2}$ / ether $1 / 1$ (427 mg, 45\%), beside the lactone rac-8 (370 mg, 45\%). Data for rac-6: white solid, $\mathrm{mp} 156^{\circ} \mathrm{C}(\mathrm{EtOH})$; IR (nujol): 3356, 3317, 3266-3016, 1726, $1636 \mathrm{~cm}^{-1} ;{ }^{1} \mathrm{H}-\mathrm{NMR}\left(300 \mathrm{MHz}, \mathrm{CDCl}_{3}\right) \delta 8.69(\mathrm{~s}, 1 \mathrm{H}), 7.22(\mathrm{~d}, J=8.8 \mathrm{~Hz}, 2 \mathrm{H}), 6.80(\mathrm{bs}, 1 \mathrm{H})$, $6.65(\mathrm{~d}, J=8.8 \mathrm{~Hz}, 2 \mathrm{H}), 3.56(\mathrm{~s}, 3 \mathrm{H}), 1.88(\mathrm{~s}, 3 \mathrm{H}), 1.82(\mathrm{~s}, 3 \mathrm{H}) ;{ }^{13} \mathrm{C}-\mathrm{NMR}\left(75 \mathrm{MHz}, \mathrm{CDCl}_{3}\right) \delta$ $174.13,169.32,156.00,131.14,127.00,115.57,61.65,53.24,23.97,21.76$. Anal. Calcd. for $\mathrm{C}_{12} \mathrm{H}_{15} \mathrm{NO}_{4}$ : C 60.75, H 6.37, N 5.90; Found: C 61.00, H 6.35, N 5.85. Data for rac-8: white solid, mp $158^{\circ} \mathrm{C}$; IR (nujol): 3322, 3283, 3067, 1810, $1650 \mathrm{~cm}^{-1} ;{ }^{1} \mathrm{H}-\mathrm{NMR}\left(300 \mathrm{MHz}, \mathrm{CDCl}_{3}\right) \delta$ $7.65(\mathrm{~s}, 1 \mathrm{H}), 7.30-7.22(\mathrm{~m}, 2 \mathrm{H}), 7.14-7.05(\mathrm{~m}, 2 \mathrm{H}), 1.83(\mathrm{~s}, 3 \mathrm{H}), 1.51(\mathrm{~s}, 3 \mathrm{H}) ;{ }^{13} \mathrm{C}-\mathrm{NMR}(75$ $\left.\mathrm{MHz}, \mathrm{CDCl}_{3}\right) \delta 176.19,169.90,152.97,129.90,129.55,124.46,122.41,110.89$ 56.81, 23.86, 21.92 .

Resolution of methyl $\boldsymbol{N}$-acetyl-a-methyl- $\alpha$-(4-hydroxyphenyl)glycinate (rac-6). HPLC resolution of rac-6 $(500 \mathrm{mg})$ dissolved in ethanol $(6.3 \mathrm{~mL})$ was carried out by successive injections, each of $0.1 \mathrm{~mL}$, on a $150 \times 20 \mathrm{~mm}$ ID column filled with the 10 -undecenoate/3,5dimethylphenylcarbamate of amylose bonded on allylsilica gel (CSP-2), and using a 91/5/4 mixture of $n$-hexane/ethanol/chloroform as eluent (flow rate, $18 \mathrm{~mL} \mathrm{~min}{ }^{-1}$ ). Three separate fractions were collected. Evaporation of the first fraction provided $235 \mathrm{mg}$ of $(R)-6$ with $98 \%$ ee. The third fraction supplied $190 \mathrm{mg}$ of $(S)-6$, in a 94/6 enantiomeric ratio. The second fraction collected $(61 \mathrm{mg})$ contained a 35/65 mixture of $(R)-6 /(S)-6$. Crystallization from ethanol of first and last fractions provided, respectively, $190 \mathrm{mg}$ of the $(R)-6$ and $130 \mathrm{mg}$ of $(S)-6$, both in optically pure form.

Spectroscopic data for both $(R)-6$ and $(S)-6$ were the same as described above for rac-6.

$(R)-6: \mathrm{Mp}=196^{\circ} \mathrm{C} .[\alpha]_{\mathrm{D}}=-21.6(c 0.37, \mathrm{EtOH}) ;(S)-6: \mathrm{Mp}=194^{\circ} \mathrm{C} .[\alpha]_{\mathrm{D}}=+21.6(c 0.45$, $\mathrm{EtOH})$.

a-Methyl-a-(4-hydroxyphenyl)glycine hydrochloride (rac-9). A solution of amido ester rac-6 (949 mg, $4 \mathrm{mmol})$ in 12N hydrochloric acid $(20 \mathrm{~mL})$ was heated under reflux for $6 \mathrm{~h}$. The solvent 
was evaporated and the resulting solid was partitioned between diethyl ether and water. The aqueous phase was washed with three additional portions of $\mathrm{Et}_{2} \mathrm{O}$ and then lyophilized to give $710 \mathrm{mg}$ of rac-9 (3.52 mmol, $88 \%$ yield). Mp 305-310 ${ }^{\circ} \mathrm{C}$ (dec.). IR (nujol) 3208-3098, 1738 $\mathrm{cm}^{-1} .{ }^{1} \mathrm{H}$ NMR $\left(\mathrm{D}_{2} \mathrm{O}, 300 \mathrm{MHz}\right) \delta 7.29(\mathrm{~d}, J=8.85 \mathrm{~Hz}, 2 \mathrm{H}), 6.79(\mathrm{~d}, J=8.85 \mathrm{~Hz}, 2 \mathrm{H}), 1.93(\mathrm{~s}$, $3 \mathrm{H}) .{ }^{13} \mathrm{C}$ NMR $\left(\mathrm{D}_{2} \mathrm{O}, 75 \mathrm{MHz}\right) \delta 174.37,156.62,127.67,127.53,116.05,61.66,21.02$.

(S)-a-Methyl- $\alpha$-(4-hydroxyphenyl)glycine hydrochloride [(S)-9]. In a similar way to that described above, starting from $(S)-6$ (94.9 mg, $0.4 \mathrm{mmol}),(S)-9$ was obtained as a white solid (74 $\mathrm{mg}, 0.37 \mathrm{mmol}, 92 \%$ yield). Spectroscopic data are the same as those described for rac-9. Mp $304-308^{\circ} \mathrm{C}$ (dec.). $[\alpha]_{\mathrm{D}}+28.2\left(c=0.27, \mathrm{H}_{2} \mathrm{O}\right)$.

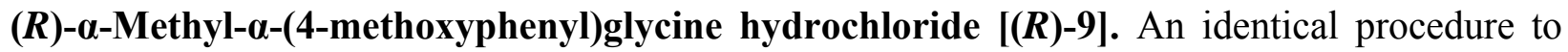
that described above was applied to transform $(R)-6$ (94.9 mg, $0.4 \mathrm{mmol})$ into $(R)-9(78 \mathrm{mg}, 0.39$ mmol, 97\% yield). Spectroscopic data are the same as those described for rac-9. Mp 300-302 ${ }^{\circ} \mathrm{C}$ (dec.). $[\alpha]_{\mathrm{D}}-29.2\left(c=0.32, \mathrm{H}_{2} \mathrm{O}\right)$.

\section{Acknowledgements}

This work was carried out with the financial support of Ministerio de Educación y Ciencia and FEDER (project CTQ2004-5358).

\section{References and Footnotes}

1. (a) Wagner, I.; Musso, H. Angew. Chem., Int. Ed. 1983, 22, 816. (b) Hunt, S. In Chemistry and Biochemistry of the Amino Acids; Barrett, G. C., Ed.; Chapman and Hall: London, 1985; p 55.

2. Williams, R. M.; Hendrix, J. A. Chem. Rev. 1992, 92, 889.

3. For reviews about $\alpha$-substituted $\alpha$-amino acids and their properties see the following: (a) Seebach, D.; Sting, A. R.; Hoffmann, M. Angew. Chem., Int. Ed. 1996, 35, 2708. (b) Wirth, T. Angew. Chem., Int. Ed. 1997, 36, 225. (c) Cativiela, C.; Díaz-de-Villegas, M. D. Tetrahedron: Asymmetry 1998, 9, 3517.

4. Mossel, E.; Formaggio, F.; Crisma, M.; Toniolo, C.; Broxterman, Q. B.; Boesten, W. H. J.; Kamphuis, J.; Quaedflieg, P. J. L. M. Tetrahedron: Asymmetry 1997, 8, 1305.

5 Shuman, R. T.; Rothenberger, R. B.; Campbell, C. S.; Smith, G. F.; Gifford-Moore, D. S.; Paschal, J. W.; Gesellchen, P. D. J. Med. Chem. 1995, 38, 4446.

6. Stilz, H. U.; Beck, G.; Jablonka, B.; Just, M. Bull. Soc. Chim. Belg. 1996, 105, 711.

7. Conn, P. J.; Pin, J.-P. Annu. Rev. Pharmacol. Toxicol. 1997, 37, 205.

8. (a) Schoepp, D. D.; Jane, D. E.; Monn, J. A. Neuropharmacology 1999, 38, 1431. (b) Watkins, J. C.; Krogsgaard-Larsen, P.; Honoré, T. Trends Pharmacol. Sci. 1990, 11, 25.

9. Watkins, J. C.; Collingridge, G. Trends Pharmacol. Sci. 1994, 15, 333. 
10. (a) Hayashi, Y.; Sekiyama, N.; Nakanishi, S.; Jane, D. E.; Sunter, D. C.; Birse, E. F.; Udvarhelyi, P. M.; Watkins, J. C. J. Neurosci. 1994, 14, 3370. (b) Sekiyama, N.; Hayashi, Y.; Nakanishi, S.; Jane, D. E.; Tse, H.-W.; Birse, E. F.; Watkins, J. C. Br. J. Pharmacol. 1996, 117, 1493. (c) Conway, S. J.; Miller, J. C.; Howson, P. A.; Clark, B. P.; Jane, D. E. Bioorg. Med. Chem. Lett. 2001, 11, 777.

11.(a) Schöllkopf, U. Pure Appl. Chem. 1983, 55, 1799. (b) Hartwig, W.; Schöllkopf, U. Liebigs Ann. Chem. 1984, 1952. (c) Remuzon, P.; Soumeillant, M.; Dussy, C.; Bouzard, D. Tetrahedron 1997, 53, 17711. (d) Ma, D.; Tian, H. Tetrahedron: Asymmetry 1996, 7, 1567. (e) Ma, D.; Tian, H. J. Chem. Soc., Perkin Trans. 1 1997, 3493. (f) Zdowsky, T. M.; de Lara, E.; Spaton, S. G. J. Org. Chem. 1990, 55, 5437.

12.(a) Ma, D.; Tian, H.; Zou, G. J. Org. Chem. 1999, 64, 120. (b) Davies, F. A.; Lee, S.; Zhang, H.; Fanelli, D. L. J. Org. Chem. 2000, 65, 8704.

13.(a) Imogai, H.; Petit, Y.; Larchevêque, M. Tetrahedron Lett. 1996, 37, 2573. (b) Matsushita, M.; Maeda, H.; Mitsuaki, K. Tetrahedron Lett. 1998, 39, 3749.

14.(a) O’Donnell, M. J.; Polt, R. L. J. Org. Chem. 1982, 47, 2663. (b) Obrecht, D.; Bohdal, U.; Broger, C.; Bur, D.; Lehmann, C.; Ruffieux, R.; Schönholzer, P.; Spigler, C.; Müller, K. Helv. Chim. Acta 1995, 78, 563.

15. (a) Coudert, E.; Acher, F.; Azerad, R. Tetrahedron: Asymmetry 1996, 7, 2963. (b) Ndzié, E.; Cardinael, P.; Schoofs, A.-R.; Coquerel, G. Tetrahedron: Asymmetry 1997, 8, 2913.

16. (a) Horikawa, H.; Nishitani, T.; Iwasaki, T.; Mushika, Y.; Inoue, I.; Miyoshi, M. Tetrahedron Lett. 1980, 21, 4101. (b) Bueno, M. P.; Cativiela, C.; Finol, C.; Mayoral, J. A.; Jaime, C. Can. J. Chem. 1987, 65, 2182. (c) Cativiela, C.; López, P.; Mayoral, J. A. Tetrahedron: Asymmetry 1991, 2, 1295.

17. (a) Horikawa, H.; Nishitani, T.; Iwasaki, T.; Inoue, I. Tetrahedron Lett. 1983, 24, 2193. (b) Srivastava, V. P.; Roberts, M.; Holmes, T.; Stammer, C. H. J. Org. Chem. 1989, 54, 5866. (c) Fernández, M. D.; De Frutos, M. P.; Marco, J. L.; Fernández-Alvarez, E.; Bernabé, M. Tetrahedron Lett. 1989, 30, 3101.

18.(a) Cardellicchio, C.; Fiandanese, V.; Marchese, G.; Naso, F.; Ronzini, L. Tetrahedron Lett. 1985, 26, 4387. (b) Pérez, M.; Pleixats, R. Tetrahedron 1995, 51, 8355.

19. Cativiela, C.; López, M. P.; Mayoral, J. A. Synlett 1992, 121.

20. Roos, E. C.; Hiemstra, H.; Speckamp, W. N.; Kaptein, B.; Kamphuis, J.; Schoemaker, H. E. Synlett 1992, 451.

21. De la Hoz, A.; Díaz-Ortiz, A.; Gómez, M. V.; Mayoral, J. A.; Moreno, A.; SánchezMigallón, A. M.; Vázquez, E. Tetrahedron 2001, 57, 5421.

22.(a) Ben-Ishai, D.; Satati, I.; Berler, Z. J. Chem. Soc., Chem. Commun. 1975, 349. (b) BenIshai, D.; Satati, I.; Bernstein, Z. Tetrahedron 1976, 32, 1571.

23. Francotte, E. R. J. Chromatogr. A 2001, 906, 379.

24.(a) Dingenen, J. In A practical approach to chiral separations by liquid chromatography, Subramanian, G., Ed.; VCH Verlagsgesellschaft: Weinheim, 1994, p 115. (b) Yashima, E.; Yamamoto, C.; Okamoto, Y. Synlett 1998, 344. 
25.(a) Franco, P.; Senso, A.; Minguillón, C.; Oliveros, L. J. Chrom., A 1998, A 796, 265. (b) Oliveros, L.; Lopez, P.; Minguillón, C.; Franco, P. J. Liq. Chrom. 1995, 18, 1521.

26.(a) Cativiela, C.; Díaz-de-Villegas, M. D.; Jiménez, A. I.; López, P.; Marraud, M.; Oliveros, L. Chirality 1999, 11, 583. (b) Alías, M.; Cativiela, C.; Jiménez, A. I.; López, P.; Oliveros, L.; Marraud, M. Chirality 2001, 13, 48. (c) Jiménez, A. I.; López, P.; Oliveros, L.; Cativiela, C. Tetrahedron 2001, 57, 6019. (d) Royo, S.; López, P.; Jiménez, A. I.; Oliveros, L.; Cativiela, C. Chirality 2002, 14, 39. (e) Cativiela, C.; López, P.; Lasa, M. Eur. J. Org. Chem. 2004, 3898.

27.(a) Gil, A. M.; Buñuel, E.; López, P.; Cativiela, C. Tetrahedron: Asymmetry 2004, 2, 1295. (b) Jiménez, A. I.; López, P.; Cativiela, C. Chirality 2005, 17, 22. (c) Gil, A. M.; López, P.; Buñuel, E.; Cativiela, C. ARKIVOC 2005, (ix), 90. 